\title{
MANAJEMEN WAKAF PRODUKTIF DAN KONTRIBUSINYA TERHADAP PENGUATAN PONDASI EKONOMI MASYARAKAT
}

\author{
Fawait Syaiful Rahman \\ Sekolah Tinggi Islam Blambangan Banyuwangi \\ fawaidsyaifulrahman@gmail.com
}

\begin{abstract}
Waqf is one of the productive efforts of an increase in welfare of society as a collective. In a community group, for example, if it turns out that many members of the community who need help, then it can be used productively endowments to help them, for with endowments productive can be obtained access to the funding sources so that generated sufficient capital. The funds obtained through productive endowments can be used as a source of capital so that it can then be used for fertilization of capital on an ongoing basis. On this occasion, the author wished to discuss the development of the following regulasinya, wakaf efforts in improving the economic empowerment of the community through endowments produkti. The methods used in this article is a qualitative approach to the library, where the focus is aimed against any reference about the Waqf and its development. The approach used is qualitative, which is a research procedure that describes the behavior of certain people, events, or places in detail and depth. While this type of research is literature. Namely, research that relies on reading sources, texts, and various information in the form of reading. In a different reference library research is research that is done to solve a problem that is based on a


critical study of library materials and related research results presented in new ways.

Keywords: Management Of Productive, Economic Endowments Of The Community.

\section{Pendahuluan}

Perbincangan tentang wakaf yang merupakan ketentuan langsung dari Allah SWT adalah kegiatan yang bernilai ibadah yang dilakukan dengan sukarela, dimana orang-orang yang melaksanakannya ada jaminan mendapatkan imbalan pahala yang besar dari Allah SWT

Pahala dari wakaf sendiri tidak akan putus, tetap mengalir dari Allah meskipun wakif telah meninggal dunia. Seperti yang tertuang dalam firman Allah QS. Ali Imran ayat 92 :

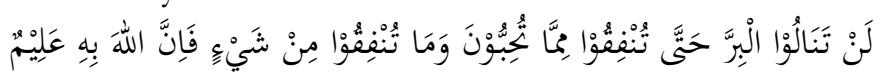

Dan hadis Rasulullah SAW:

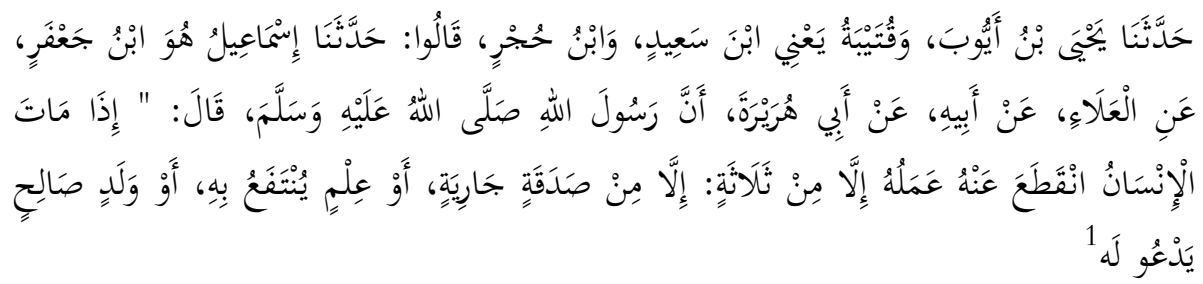

Artinya: Kami (Muslim) diberitahu oleb Yabya bin Ayyub dan Qutaibah (yakni ibn Sa'ad) serta Ibnu Hujr, mereka, mereka berkata: "Kami diberitabui oleh Ismail (yakni Ibn Ja'far), dari Al'Ala' dari bapaknya dari Abu Hurairah babwa Rasulullah saw. bersabda : "Apabila seorang manusia meninggal dunia, terputuslab darinya amalnya kecuali dari tiga, yakni kecuali sedekah jariyah, atau ilmu yang diambil manfaatnya, atau anak shaleb yang mendoakannya". (HR. Muslim)

Pada hakikatnya manusia mengenal kebaikan yang tidak terhitung jumlahnya, termasuk tema tentang wakaf dan diantaranya tentang pertukaran wakaf. Menurut Ibnu Abidin pertukaran wakaf bisa terjadi dalam tiga kondisi. Pertama, apabila wakif telah memberi syarat tentang pertukaran wakaf, maka ini diperbolehkan berdasarkan ijma' dalam

\footnotetext{
1 Abu Husain Muslimin al-Hajjâj bin Muslim al-Qushairi al-Naisaburi, Shahîh Muslim Jilid 3, (Beirut: Dar al-Af aq al-Jadîdah, t:th), 1255
} 
madzhab hanafi. Kedua, adanya perubahan pada wakaf, sehingga tidak semuanya bisa dimanfaatkan. Ketiga, wakaf masih bisa dimanfaatkan secara utuh namun ditukar dengan barang lain yang lebih baik dan menghasilkan. ${ }^{2}$

Di Indonesia Wakaf dilaksanakan menurut pemahaman dan kepercayaan masyarakat. Sebelum adanya peraturan perundangundangan, pelaksanaan wakaf masyarakat Indonesia cenderung secara lisan, saling percaya antara wakif dan nadzir atau lembaga tertentu. Pelaksanaan semacam itu disebabkan karena masyarakat menganggap masalah wakaf adalah masalah yang berhubungan langsung dengan tuhan, sehingga pelaksanaan wakaf hanya dicukupkan secara lisan dan berdasarkan kepercayaan dan tidak memerlulan aturan administratif. Imbas dari hal tersebut adalah mempercayai bahwa urusan wakaf tidak ada ang berani mengganggu, sebab berkaitan langsung dengan Allah. ${ }^{3}$

Mengingat betapa pentingnya masalah tanah, selain itu problematika tanah wakaf semakin kompleks, banyak terdapat tanah wakaf digugat kembali oleh keluarga wakif meskipun sudah bertahuntahun dimanfaatkan untuk ibadah, maka dalam rangka menanggulangi perihal demikian dan diharapkan tidak berkelanjutan pemerintah bersama DPR RI akhirnya menetapkan Undang-undang tentang Pokok-pokok Agraria No. 5 Thn. 1960 yang disahkan pada tanggal 14 September 1960. Dalam konsideran huruf "a" disebutkan:

Bahwa berhubung dengan apa yang tersebut dalam pertimbanganpertimbangan di atas perlu adanya Hukum Agraria Nasional yang berdasar atas hukum adat tentang tanah, yang sederhana dan menjamin kepastian hukum bagi seluruh rakyat Indonesia dengan tidak mengabaikan unsur-unsur yang bersumber pada hukum agama. ${ }^{4}$

Dalam Undang-undang Pokok Agraria pasal 49 ayat (3) disebutkan bahwa perwakafan tanah milik dilindungi dalam Peraturan Pemerintah (PP). Ayat (1) menyatakan:

"Hak milik badan-badan keagamaan dan sosial sepanjang dipergunakan untuk usaha dalam bidang keagamaan dan sosial, diakui dan dilindungi. Badan-badan tersebut dijamin pula akan

\footnotetext{
${ }^{2}$ Ibnu Abidin, Hasyiyah Ibnu Abidin, (Cairo: Dar Assalam, tt), 60

3 Departemen Agama RI, Paradigma Baru Wakaf di Indonesia, (Jakarta: Direktorat Pemebrdayaan Wakaf dan Direktorat Jendral Bimbingan Masyarakat Islam, 2007), 97

${ }^{4}$ Departemen Agama RI, Himpunan Peraturan Perundang-undangan Tanah Milik, Proyek. Pembinaan Zakat dan Wakaf, cet. 4 (Jakarta: tnp., 1984/1985), 1
} 
memperoleh tanah yang cukup untuk bangunan dan usahanya dalam bidang keagamaan dan sosial."5

Pemerintah mengeluarkan PP No. 28 Th. 1977 tentang Perwakafan Tanah Milik sebagai tindakan berkelanjutan, yang ditetapkan tanggal 17 Mei 1977. Sebelumnya, UUPA pasal 19 ayat (1) mengatur bahwa:

"Untuk menjamin kepastian hukum diadakan pendaftaran tanah di seluruh wilayah RI oleh pemerintah menurut Peraturan Pemerintah". ${ }^{6}$

Karena itu pemerintah telah berusaha membuat aturan-aturan untuk memecahkan masalah perwakafan. Aturan-aturan ini walaupun belum sepenuhnya dapat dilaksanakan, namun sedikit banyak telah membantu menyelesaikan persoalan yang terjadi ${ }^{7}$ dan harus sesuai dengan Peraturan Pemerintah. Namun, biasanya bila seseorang mewakafkan tanah miliknya, wakif menunjuk nâzir untuk menyelesaikan segala sesuatunya yang berhubungan dengan pelaksanaan wakaf termasuk pengurusan PPAIW. Dalam praktek, nâzir kadang mengalami kesulitan karena salah satu syarat yang diajukan berupa sertifikat tanah hak milik, sementara wakif belum memiliki sertifikat tanah yang diwakafkan, padahal sertifikat tanah merupakan sesuatu yang sangat penting sebagai bukti kepemilikan tanah tersebut, sebagaimana telah diatur oleh UUNomor 41 Tahun 2004.

Dalam rangka menertibkan tanah wakaf maka pemerintah mengeluarkan aturan yang mengatur ketertiban masalah wakaf seperti yang tertuang dalam Intruksi Presiden No. 1 Th. 1991 tentang Kompilasi Hukum Islam, UU No 41 Th. 2004 tentang wakaf, PP No 42 Th. 2006 tentang pelaksanaan Peraturan Pemerintah Nomor 41 tahun 2004.

Kondisi wakaf setelah pemerintah mengeluarkan peraturan di atas yang diharapkan menjadi solusi konkrit masalah wakaf ternyata sertifikat tanah wakaf masih banyak ditemukan yang tidak memiliki sertifikat. Hal ini memberi petunjuk bahwa masalah wakaf belum teratasi dengan maksimal, dan perlu perhatian khusus dalam rangka menertibkan dan menjamin sertifikasi tanah wakaf agar terjamin keamanannya dari administrasi hingga kepastian hak bila terjadi sengketa atau masalah hukum.

${ }^{5}$ Ibid, 18.
${ }^{6}$ Ibid, 10.

${ }^{7}$ Saroso \& Nicongani, Tinjauan Yuridis tentang Perwakafan Tanah Milik, Seri Hukum Agraria No.1 (Yogyakarta: Liberty, 1984), 43

20 Fawait Syaiful Rahman - Manajemen Wakaf Produktif 
Setelah UU Nomor 41 Tahun 2004 disahkan dan PP Nomor 42 Tahun 2006 tentang pelaksanaanya diharapkan untuk jangka panjang masalah gugat-menggugat tanah wakaf tidak ada lagi. ${ }^{8}$

Perjalanan wakaf di Indonesia dari klasik hingga dikeluarkannya UU wakaf dalam KHI atau PP yang mengatur tentang implementasinya ternyata masih menyisihkan banyak hal dikalangan masyarakat. Masalah tersebut meliputi ketidakjelasan bukti autentik siapa pemilik dari tanah yang diwakafkan, dan biasanya ini terjadi disaat wakif telah meninggal dunia dan tanah yang diwakafkan belum disertifikatkan, sehingga generasinya (keturunan wakif) dengan mudah melakukan gugatan kepada nadzir yang dipasrahi secara lisan.

Karena fenomena perkembangan wakaf di Indonesia semakin menguat hingga sekarang, maka artikel ini dibuat dalam rangka mengupas secara tuntas segela sesuatu yang berhubungan dengan wakaf, baik secara teori dan prosedur implementasinya terhadap pemberdayaan ekonomi ummat. Pembahasan di dalam artikel ini diharapkan memuat secara komprehensif dan integrasi kajian wakaf dari klasik hingga komtemporer agar dapat dijadikan salah satu sumber referensi bagi khalayak umum.

\section{Metode Penelitian}

Pendekatan yang digunakan adalah kualitatif, yaitu suatu prosedur penelitian yang mendeskripsikan perilaku orang, peristiwa, atau tempat tertentu dengan rinci dan mendalam. Sedangkan jenis penelitian ini adalah pustaka. Yaitu penelitian yang bertumpu pada sumber-sumber bacaan, teks-teks, dan berbagai informasi yang berbentuk bacaan. ${ }^{9}$ Dalam referensi yang berbeda penelitian kepustakaan adalah penelitian yang dikerjakan untuk memecahkan suatu masalah yang bertumpu pada studi kritis terhadap bahan-bahan pustaka dan hasil penelitian terkait yang disajikan dengan cara baru. ${ }^{10}$

Marzuki menyebutkan ${ }^{11}$ (library research), yaitu penelitian yang dilaksanakan dengan menggunakan literatur (kepustakaan), baik barupa

\footnotetext{
8 Abdurrahman, Masalah Perwakafan Tanah Milik dan Kedudukan Tanah Wakaf di Negara Kita, cet. 4 (Bandung: Citra Aditya Bakti, 1994), 10.

${ }^{9}$ Bungin, Burhan. Metodologi Penelitian Sosial, (Sidoarjo: Airlangga University Press. 2001), 48

${ }^{10}$ Padmo Sukoco, Penelitian Kualitatif: Metodologi, Aplikasi, dan Evaluasi, (Jakarta: Gunung Agung, 2002), 209.

${ }^{11}$ Kajian pustaka pada umumnya menggunakan metode pendekatan kualititatif, sebagai prosedur penelitian, metode ini menghasilkan data deskriptif berupa kata-kata tertulis atau lisan. Lihat Marzuki, Metodologi Riset, (Yogyakarta: Ekonisia, 2005), 14.
} 
buku, catatan, maupun laporan hasil penelitian terdahulu. ${ }^{12}$ Kajian pustaka juga diartikan proses umum yang dilakukan peneliti dalam upaya menemukan teori. ${ }^{13}$

\section{Harta Wakaf}

\section{Pengertian dan Sumber Hukum}

Kata Wakaf merupakan derivasi dari Waqafa dalam bahasa arab. Arti lafadz Waqafa adalah berhenti atau menahan, dan bisa juga diartikan dengan tidak bergerak di tempat atau tetap berdiri. ${ }^{14}$

Wakaf menurut Abu Hanifah dan sebagaian ulama Hanafiyah: adalah menahan benda yang statusnya tetap milik waqif (orang yang mewakafkan hartanya), sedangkan yang disedekahkan adalah manfaatnya.

Wakaf menurut Malikiyah adalah memanfaatkan benda yang dimiliki untuk dimanfaatkan orang yang kompeten baik berupa sewa atau hasil sewa, dengan jangka waktu menurut kehendak waqif. Wakaf menurut Shafi'iyah adalah penahanan harta yang dapat dimanfaatkan zat benda bersifat kekal. Sedangkan Hanabilah menjelaskan wakaf adalah aktifitas menahannya pemilik harta dalam memanfaatkan hartanya dan zat benda yang bersifat kekal serta meniadakan wewenang atas benda itu, dan manfaatnya digunakan dalam hal ibadah Allah. ${ }^{15}$

Selanjutnya Mundzir Qahaf berpendapat bahwa wakaf adalah pemilik harta memberikan harta atau pokok benda yang bisa dimanfaatkan agar disalurkan hasil dan manfaatnya secara khusus sesuai dengan tujuan wakaf, baik untuk kepentingan perorangan, masyarakat, agama atau umum. ${ }^{16}$

Menurut UU No. 41 Th. 2004 wakaf adalah perbuatan hukum waqif untuk memisahkan dan/atau menyerahkan sebagian harta benda miliknya untuk dimanfaatkan selamanya atau untuk jangka waktu tertentu sesuai dengan kepentingan untuk keperluan ibadah atau kesejahteraan umum menurut syari'ah. ${ }^{17}$ Berbeda dengan hal tersebut menurut PP Nomor 28 tahun 1977 wakaf adalah memisahkannya seseorang atau

\footnotetext{
12Sangadji, Metodologi Penelitian Pendekatan Praktis dalam Penelitian, 28. Untuk lebih mempermudah dalam memahami, penelitan pustaka (library research) adalah penelitian yang digolongkan menurut tempat penelitian itu dilaksanakan. Mardalis, Metode Penelitian Suatu Pendekatan Proposal, 28

${ }^{13}$ Mundir, Metode Penelitian Kualititatif \& Kuantitatif, 140.

14 Wahbah Zuhayli, Al-Fiqhu al-Islami wa 'Adillatubu Juz 8, (Damaskus: Dar al-Fikr, 1985), 153

${ }^{15}$ Ibid, 156

${ }^{16}$ Bahsul Hazami, Jurnal Analis, Peran dan aPlikasi Wakaf dalam Mewujudkan Kesejabteraan Umat di Indonesia, Juni 2016

${ }^{17}$ Pasal 1 ayat 1 Undang-Undang Wakaf Nomor 1 Tahun 2004
} 
badan hukum terhadap harta kekayaannya seperti tanah milik dan melembagakan untuk selama-lamanya sebagai peribadatan atau keperluan bersifat umum sesuai dengan ajaran Islam. ${ }^{18}$

Sedangkan Wakaf dalam Kompilasi Hukum Islam adalah perbuatan hukum seseorang atau kelompok orang atau badan hukum dengan memisahkan sebagian dari benda miliknya dan melembagakannya untuk selama-lamanya guna kepentingan ibadah atau keperluan umum lainnya sesuai dengan ajaran Islam. ${ }^{19}$

Pengertian menurut ulama dan hukum positif di Indonesia beda pendapat tentang kekalnya penyerahan zat benda, dimanfaatkan selamanya dan atau untuk jangka waktu tertentu. Perlu dipahami bahwa dengan perbedaan pendapat tersebut memberikan kelonggaran pemikiran bagi para cendikiawan muslim Indonesia untuk memilih sala satu dari pendapat tersebut dalam pengembangan dan pemberdayaan wakaf produktif di Indonesia. Dan tidak hanya pemahaman terhadap teks saja melainkan kepada kondisi masyarakat.

Wakaf bisa disebut juga dengan salah satu bentuk filantropi (kedermawanan) sebagai realisasi ibadah kepada Allah, yang senantiasa dianjurkan pengamalannya sebagaimana terlihat dalam pesan-pesan ajaran Islam. Sebagai ibadah yang telah disyariatkan, masalah wakaf mempunyai dasar hukum, baik dari Al-Qur'an maupun sunnah. Ayat Alquran yang dipandang sebagai dasar hukum wakaf, antara lain :

Keterangan di dalam QS Ali Imran ayat 192 sebagai berikut :

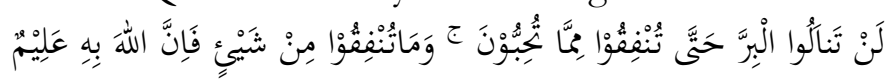

Begitu juga dengan ayat QS. Al-Hajj : 77:

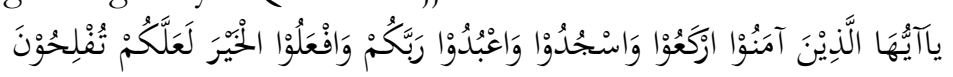

Selain itu juga disebutkan dalam QS al-Baqarah: 261 yaitu :

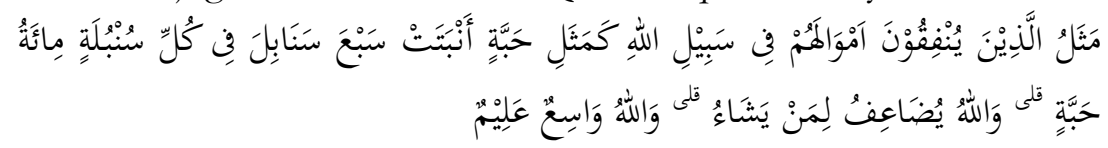

Dan QS. Al-Baqarah : 267:

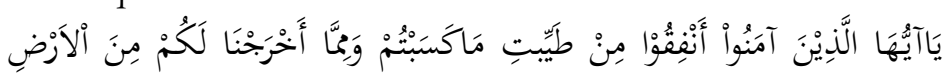

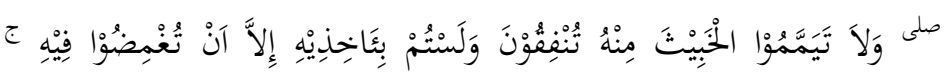

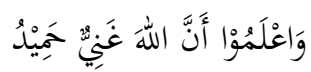

\footnotetext{
18 Pasal 1 ayat 1 PP. No. 28 Tahun 1977

${ }^{19}$ Pasal 215 ayat 1 Buku III Hukum Perwakafan Kompilasi Hukum Islam
} 
Dari beberapa pengertian di atas dapat disimpulkan yang dimaksud dengan wakaf adalah perbuatan seseorang untuk memisahkan sebagian harta benda/harta miliknya untuk kemudian dimanfaatkan kepentingan ibadah dan kesejahteraan umum.

\section{Syarat sah Wakaf}

Keabsahan wakaf bisa terjadi apabila telah terpenuhi rukun dan syaratnya. Untuk kriteria wakaf, terjadi perdebatan di kalangan ulama. Hal ini terjadi karena berbeda dalam menerapkan apa yang dimaksud dengan rukun akad. Ulama Hanafiyah menjelaskan Rukun wakaf adalah shighat, yaitu lafadz yang menunjukkan makna wakaf, maka dari itu yang menjadi rukun wakaf menurut mereka adalah ijab, yaitu pernyataan yang bersumber dari waqif yang menunjukkan kehendak wakaf. Sedangkan Qabul dari penerima wakaf tidak termasuk dalam rukun wakaf menurut ulama Hanafiyah. Sementara itu menurut jumhur ulama rukun wakaf ada empat yaitu waqif, manquf, manqu alaih, dan shighat. ${ }^{20}$

Sebagaimana disebutkan dalam salah satu kitab fikih bahwa rukun wakaf terdiri dari $W$ akif (orang yang mewakafkan), Mauquf 'alaib (tujuan wakaf), Mauquf (harta benda wakaf), dan shighat (pernyataan atau ikrar wakaf). ${ }^{21}$ sedangkan Undang-Undang Nomor 41 Tahun 2004 pada pasal 6 menyatakan bahwa wakaf dilaksanakan dengan memenuhi unsur wakaf sebagai berikut:

Wakif

Wakif adalah pihak yang mewakafkan. Wakif harus mempunyai kecakapan hukum. Seorang wakif bisa dikatakan memiliki kecakapan hukum, jika memenuhi empat kriteria yaitu berakal, baligh, tidak dalam tanggungan karena fasib (boros) dan ghaflah (bodoh), dan kemauan sendiri. ${ }^{22}$

\section{Nâzir}

Nâzir adalah pengelola wakaf yang berkewajiban menjaga harta wakaf, mengembangkan, mengeksploitasi, memanfaatkan dan membagikan keuntungannya kepada mereka yang berhak. ${ }^{23}$

Harta benda wakaf

\footnotetext{
${ }^{20}$ Rozalinda, Manajemen Wakaf Produktif, (Jakarta: Raja Grafindo Persada, 2015), 22

${ }^{21}$ Nuruddin al-Khadami, Al-Waqf al-'Alami, (Tunisia: tp, 2006), 14

${ }^{22}$ Miftahul Huda, Mengalirkan Manfaat Wakaf, (Bekasi: Gramata Publishing, 2015), 42

${ }^{23}$ Rozalinda, Manajemen Wakaf Produktif, 40
} 
Harta benda wakaf adalah harta yang diwakafkan merupakan barang yang jelas wujudnya, milik orang yang mewakafkan, serta manfaatnya yang bertahan lama untuk digunakan. ${ }^{24}$

\section{Ikrar wakaf}

Ikrar wakaf atau shighat adalah pernyataan penyerahan harta benda wakaf oleh wakif. ${ }^{25}$

Peruntukan harta wakaf

Dalam rangka mendapatkan tujuan dan fungsi waka maka harta benda wakaf dapat diperuntukkan untuk sarana prasarana dan aktifitas ibadah, sarana untuk kegiatan pendidikan dan kesehatan, anak terlantar, membiayai anak yatim piatu, menyalurkan beasiswa, kemajuan dan peningkatan ekonomi umat, atau kemajuan kesejahteraan umum lainnya yang tidak bertentangan dengan syariah dan peraturan perundang-undangan.

Jangka waktu wakaf.

Saat ini wakaf dapat diberikan jangka waktu, yaitu pada instrumen wakaf uang. ${ }^{26}$

Dari berbagai ketentuan wakaf menurut para pakar hukum fikih dan Undang-undang yang mengaturnya bahwa masalah wakaf mendapat perhatian serius, terbukti dari tawaran para pakar terkait pengertian dan ketentuan wakaf sangat ketat sekali.

\section{Manajemen Pengelolaan Wakaf di Indonesia}

Manajemen pengelolaan berada pada posisi teratas dan paling urgen dalam mengelola dan memberdayakan tanah wakaf. ${ }^{27}$ George R. Terry menjelaskan bahwa manajemen adalah proses yang khas yang terdiri atas tindakan-tindakan yang berupa perencanaan, pengorganisasian, pelaksanaan dan pengendalian bidang masing-masing dengan menggunakan sains dan seni yang dilakukan secara berurutan demi mencapai sasaran yang telah ditetapkan dengan memanfaatkan

\footnotetext{
${ }^{24}$ Muh. Fudhail Rahman, 2009. Wakaf Dalam Islam, Jurnal, Fakultas Syariah dan Hukum Jakarta

${ }^{25}$ Miftahul Huda, Mengalirkan Manfaat Wakaf, 57

${ }^{26}$ M. Nur Rianto Al Arif, 2012. Jurnal Ilmu Syariah dan Hukum, Efek Multiplier Wakaf Uang dan Pengarubnya terhadap Program Pengentasan Kemiskinan.

${ }^{27}$ Farid Wadjdy \& Mursyid, Wakaf dan Kesejabteraan Umat, (Samarinda: Pustaka Pelajar, 2007), 174
} 
sumber daya manusia dan sumber daya lainnya. ${ }^{28}$ Sedangkan Menurut Stoner ada 4 tahap yang dilakukan dalam manajemen pengelolaan yaitu:

\section{Perencanaan}

Kata perencanaan hampir mirip dengan istilah musyawarah, gambaran konkritnya yaitu proses upaya yang dilakukan untuk penentuan strategi dan taktik yang tepat untuk mewujudkan target dan tujuan organisasi sekaligus mengantisipasi kecenderungan di masa yang akan dating.

Pengorganisasian

Yaitu struktur dari wewenang atau kekuasaan nâzir atau bisa pula diartikan dengan suatu kerangka tingkah laku untuk analisis proses pengambilan keputusan organisasi.

Pelaksanaan

Yaitu proses implementasi program yang direncanakan agar bisa dijalankan oleh semua pihak (para nâqir) serta proses memotivasi agar dapat menjalankan tanggung jawab dengan penuh kesadaran dan produktifitas yang tinggi.

Pengawasan

Yaitu proses yang dilakukan untuk memastikan rangkaian kegiatan yang direncanakan, diorganisasikan, dan diimplementasikan berjalan sesuai target yang diharapkan sekalipun berbagai perubahan terjadi. ${ }^{29}$

Secara empirik, mengelola wakaf secara profesional merupakan suatu hal yang tidak mudah. Di sini dibutuhkan suatu keahlian, kesungguhan dan keuletan yang intens. Alasan tersebut menyebabkan pengelolaan wakaf Indonesia menimbulkan beberapa problematika yang hingga kini masih kita jumpai, antara lain:

Pertama, adanya kebekuan umat Islam terhadap pemahaman wakaf. Secara umum masyarakat Indonesia melaksanakan wakaf mengikuti madzhab Syafi'i yang telah berintegrasi dengan adat kebiasaan setempat. Seperti melaksanakan wakaf secara lisan dan atas dasar saling percaya, memandang wakaf sebagai amal shaleh dengan nilai mulia disisi Allah tanpa melalui prosedur administratif, dan harta wakaf dianggap milik Allah sehingga tidak ada yang berani melakukan kecurangan.

\footnotetext{
28 Jaih Mubarok, Wakaf Produktif, (Bandung: Simbiosa Rekatama Media, 2008), 30

${ }^{29}$ Farid Wadjdy \& Mursyid, Wakaf dan Kesejabteraan Umat, (Samarinda: Pustaka Pelajar, 2007), 174
} 
Kedua, nadzir wakaf yang tradisional-konsumtif. ${ }^{30}$ Keberadaan nadzir (pengelola) yang masih tradisional dipengaruhi oleh beberapa faktor, diantaranya:

a. Paradigma mayoritas umat Islam lebih mementingkan aspek keabadian benda wakaf dari pada kemanfaatannya. Disinilah kemudian benda-benda wakaf tidak bisa dikembangkan secara lebih optimal.

b. Kualitas Sumber Daya Manusia (SDM) nadzir waqf terbilang masih rendah. Dalam mempercayakan harta wakaf kepada nadzir cenderung didasarkan pada kepercayaan kepada tokoh agama seperti kyai atau ustadz, sedangkan dalam masalah manajerial bisa dibilang kurang mampu.

c. Nadzir masih mengambil keuntungan secara sepihak dengan menyalahgunakan peruntukan benda wakaf. Contoh seperti menyewakan tanah wakaf untuk bisnis untuk kepentingan pribadi, dan ada juga yang secara sengaja menjual dengan pihak ke tiga dengan cara yang tidak sah. ${ }^{31}$

Masalah Wakaf produktif bukan hal yang baru, sebab praktek wakaf sudah ada sejak zaman Rasulullah, hanya saja dalam pelaksanaan wakaf selama ini lebih banyak berupa benda-benda tidak bergerak dan peruntukannya terbatas pada kepentingan ibadah, seperti masjid, mushalla, pesantren, dan kuburan. Wakaf kemudian diharapkan menjadi salah satu media untuk dapat membangun harta secara produktif melalui kegiatan investasi dan produksi saat ini, agar bermanfaat untuk generasi yang akan datang. Manfaat harta wakaf diharapkan menjadi alternatif pemecahan masalah dari problem harta wakaf ke arah produktif yang berorientasi pada sosial, dan hasilnya bisa dirasakan masyarakat. ${ }^{32}$

Makna wakaf produktif adalah wakaf yang memiliki manfaat dan dapat dikembangkan terus menerus secara ekonomis. Harta wakaf (tanah) sebagai faktor produksi berdasarkan Undang-Undang Nimor 41 Tahun 2004 harus dikelola dengan baik. Harta wakaf sebagai benda dalam bentuk fisik dapat dikerjakan oleh manusia, dalam sitilah ekonomi yaitu benda tersebut dapat dikelola manusia agar menjadi berguna (dihasilkan). ${ }^{33}$

\footnotetext{
30 Ahmad Syukron, Rekonstruksi Hukum Islam: Kajian Historis Atas Urgensi Pelembagaan Wakaf Produktif di Indonesia, (Jurnal Penelitian: 2011), 279

${ }^{31} \mathrm{Ibid}, 280$

32 Mundzir Qahaf, Manajemen Wakaf Produktif, terjemah Rida, Mas Muhyiddin, (Jakarta: Khalifa, 2005), 1905

33 M. Abd Manan, Ekonomi Islam Teori dan Praktek,M. Nastangin (terj). (Yogyakarta: Dana Bhakti Wakaf, 1993), 54
} 
Indonesia dengan penduduk muslim terbanyak diseluruh dunia, diharapkan upaya penggalangan dan pengelolaan wakaf lebih produktif sehingga masyarakat bisa lebih mengapresiasi. Kenyataannya masalah wakaf di Indonesia cukup serius, khususnya yang terkait dengan pelembagaan dan pengelolaan. Selama ini pengelolaan wakaf di Indonesia belum bisa dikatakan maksimal, seperti pengelola (nadzir) yang tidak profesional, selain itu kerangka kerja belum jelas kemana arahnya, akhirnya dampak dari masalah tersebut belum bisa menjawab kebutuhan masyarakat. ${ }^{34}$

Undang-undang Nomor 41 tahun 2004 tentang wakaf telah mengatur harta benda yang dapat diwakafkan. Seperti wakaf bisa dari benda tidak bergerak dan benda bergerak. Wakaf uang/tunai termasuk benda bergerak yang diselenggarakan melalui lembaga keuangan syari'ah. Mannan memberi tawaran menarik tentang wakaf, yaitu wakaf tunai. Wakaf tunai merupakan alternatif untuk memcahkan masalah wakaf di Indonesia yang cenderung jumud. Wakaf tunai memiliki beberapa keunggulan diantaranya memperluas jangkauan jumlah wakif, sebab seseorang tidak perlu menjadi tuan tanah dulu untuk berwakaf. Selain itu masalah wakaf menjadi lebih fleksibel, mengingat wakaf bisa dilakukan dalam bentuk tunai.

Di Bangladesh wakaf telah dikelola oleh Social Investment Bank Ltd (SIBL). Bank ini telah mengembangkan Pasar Modal Social (the Valuntary Capital Market). Instrumen-instrumen keuangan Islam yang telah dikembangkan, antara lain : surat obligasi pembangunan perangkat wakaf (Qafw Properties Development Bond), sertifikat wakaf tunai (Cash Waqf Deposit Certificate), sertifikat wakaf keluarga (Family Waqf Certificate), obligasi pembangunan perangkat masjid Mosque Peoperties Development Bond), Quartz-Hasana Certificate, sertifikat pembayaran zakat (Zakat/Ushar Payment Certificate), sertifikat simpanan Haji (Hajj Saving Certificate), dan lain-lain. ${ }^{35}$

Mannan, pakar ekonomi Islam asal Bangladesh mengemukakan bahwa sertifikat wakaf tunai Cash Waqf Certivicate (SWT) merupakan upaya inovasi finansial di bidang perwakafan. Bila langkah ini berhasil dijalankan dengan baik, akan mampu memberikan manfaat untuk kesejahteraan umat, contohnya adalah yang pernah dilakukan di Bangladeh, yang menuai kesuksesan besar. Jika ada organisasi Lembaga Wakaf yang mendapat perhatian khusus dan dikelola secara profesional maka tidak menutup kemungkinan akan menarik minat muslim kelas

\footnotetext{
${ }^{34}$ Mukhlisin Muzarie, Fiqh Wakaf, (Yogyakarta: Dinamika STAIC Press, 2010), 7

${ }^{35}$ Kementrian Agama RI, Panduan Pengelolaan Wakaf Tunai, Jakarta: Direktorat Jendral Bimbingan Masyarakat Islam Direktorat Pemberdayaan Wakaf, 2013), 114
} 
menengah untuk ikut berpartisipasi dalam menggalakkan wakaf, dan itu artinya pengentasan kemiskinan di Indonesia mulai berhasil. ${ }^{36}$

Dalam Pasal 28 UU Nomor 41 Tahun 2004 menjelaskan tentang Wakif dapat mewakafkan benda bergerak berupa uang melalui lembaga keuangan syariah yang ditunjuk oleh Menteri. ${ }^{37}$

Setelah disahkannya UU Nomor 41 Tahun 2004 merupakan terobosan baru yang mengubah paradigma wakaf tradisional konsumtif menjadi paradigma wakaf produktif.

Untuk kasus Indonesia sistem perwakafan yang sesuai adalah sistem yang terdesentralisasi dan plural. Tapi badan wakaf yang dibentuk oleh civil society ${ }^{38}$ juga dibolehkan. Pemerintah bahkan bisa memberikan insentif lewat ketentuan dalan Undang-Undang wakaf, bahwa infak dalam bentuk wakaf bisa dibebaskan dari kewajiban pajak. ${ }^{39}$

Salah satu bentuk kepedulian dan refleksi dari kalangan civil society adalah Dompet Dhuafa Republika, di dalamnya masyarakat muslim bisa mengelola dengan sistem yang berlaku dalam Islam. Sistem ini tidak hanya menguntungkan masyarakat akan tetapi hal ini mendukung program pemerintah. Dengan keadaan seperti ini akan membuka peluang bagi pemberdayaan wakaf produktif sebagai upaya dalam meningkatkan kesejahteraan masyarakat.

Salah satu jalan untuk melakukan optimalisasi fungsi wakaf sebagai sarana sekaligus prasarana peningkatan kualitas hidup manusia maka perlu merubah pemahaman atau gaya umat Islam yang beranggapan harta wakaf hanya terbatas harta tidak bergerak yang tidak dapat diproduktifkan seperti kuburan, masjid, yayasan, pesantren dan sebagainya. Di dalam PP Perwakafan berupa UU No. 41 Tahun 2004 tentang Wakaf dan PP. No. 42 Tahun 2006 tentang Pelaksanaannya disimpulkan bahwa tujuan utama pemberdayaan wakaf disamping untuk kepentingan ibadah, juga pemberdayaan wakaf secara produktif untuk kepentingan sosial (kesejahteraan umat). ${ }^{40}$

\section{Pemberdayaan Ekonomi Umat melalui Wakaf}

\section{Pasal 34 amandemen UUD 1945 disebutkan;}

\footnotetext{
36 Ibid, 113

${ }^{37}$ Undang-Undang Nomor 41 Tahun 2004, 7

38 Masyarakat madani (dalam bahasa Inggris civil society) dapat diartikan sebagai suatu masyarakat yang beradab dalam membangun, menjalani dan memaknai kehidupannya. (http://id.m.wikipedia.org)

39 Achmad Djunaidi dan Thobib Al-Asyhar, Menuju Era Wakaf Produktif, Jakarta: Mumtaz Publishing, 2007), 72

${ }^{40}$ Ibid, 90
} 
"Bahwa negara mengembangkan sistem jaminan sosial bagi selurub rakyat dan memberdayakan masyarakat yang lemah dan tidak mampu sesuai dengan martabat kemanusiaan".

Sebagai penyelenggara negara, seharusnya pemerintah memberikan fasilitas berupa sarana dan prasarana dalam memberdayakan masyarakat sebagai langkah konkrit, tujuannya adalah membantu masyarakat agar menjadi mandiri baik dalam hal ekonomi dan kesejahteraan umum. ${ }^{41}$

Wakaf di samping berfungsi 'ubudiyah juga berfungsi social dengan rasa solidaritas yang tinggi antara sesama manusia. Oleh karenanya pemberdayaan wakaf adalah mewujudkan dan memelihara hubungan dengan Allah SWT yaitu hablun min Allah dan hubungan sesama manusia yaitu hablun min an-nas. Manfaat yang lebih besar dari wakaf adalah diharapkan akan menjadi bekal bagi kehidupan orang yang berwakaf (wakif) di hari kemudian, mengingat amal pahalanya akan mengalir secara terus menerus selama harta wakaf itu dimanfaatkan, seperti yang ditegaskan dalam hadis riwayat HR. Muslim. ${ }^{42}$

Manfaat dari pemberdayaan wakaf, selain berfungsi sebagai usaha pembentukan watak dan kepribadian seorang muslim agar rela melepaskan sebagian hartanya demi kepentingan orang lain, juga sebagai simpanan yang bernilai dengan jangan waktu tidak terbatas. Sasaran dari pemberdayaan wakaf adalah pemerataan kesejahteraan umat dan kemiskinan, dan tidak sekaligus kaum kerabat yang membutuhkan pertolongan. ${ }^{43}$

Jika dilihat dari segi kemanfaatannya, wakaf produktif sangat potensial bagi pembangunan dan kepentingan umat sebingga jelas lebih menguntungkan bagi pemberdayaan ekonomi umat. ${ }^{44}$

Pertama, wakaf produktif akan terasa manfaatnya dan dapat dinikmati oleh masyarakat untuk kepentingan kemanusiaaan dan umat secara lebih luas, tidak hanya untuk kalangan tertenntu, terlebih lagi dalam kondisi sebagian masyarakat yang belum memiliki tingkat kesejahteraan yang menggembirakan.

Kedua, wakaf prooduktif tidak hanya dapat digunakan untuk sarana kepentingan tertentu, namun juga dapat dipergunakan sebagai

\footnotetext{
${ }^{41}$ M. Nur Rianto Al Arif, 2012. Jurnal Ilmu Syariah dan Hukum, Efek Multiplier Wakaf Uang dan Pengarubnya terbadap Program Pengentasan Kemiskinan

42 Pasal 22 Undang-Undang Nomor 41 Tahun 2004

${ }^{43}$ Satria Effendi, Problematika Hukum Keluarga Islam Kontemporer, Analisis Yurisprudensi dengan Pendekatan Ushuliyah, (Jakarta: Kencana Prenada Media Group, 2010), 409

${ }^{44}$ Nahed Nuwairah, 2009. Pemberdayaan Ekonomi Umat Melalui Wakaf, Jurnal Kajian Islam.
}

30 Fawait Syaiful Rahman - Manajemen Wakaf Produktif 
sarana pembangunan umat di berbagai bidang, seperti jaminan sosial, pendidikan, kebudayaan, ekonomi masyarakat, kesehatan dan lain-lain.

Ketiga, wakaf produktif merupakan upaya meminimalisir kesenjangan ekonomi di masyarakat karena agama Islam menghendaki agar kekayaan tidak beredar di antara orang-orang kaya saja, tetapi harus didistribusikan kepada masyarakat. Sebagai contoh, wakaf produktif berbentuk perusahaan atau usaha, maka menjadikan harta wakaf menjadi berkembang dan sekaligus membuka lapangan usaha baru bagi orangorang yang membutuhkan lapangan.

Keempat, wakaf produktif merupakan salah satu upaya peningkatan kesejahteraan masyarakat secara kolektif. Kondisi masyarakat yang tidak merata, dari tingkat rendah, menengah, hingga atas seringkali menyebabkan terjadinya ketimpangan. Salah satu alternatif penyelesaian masalah dari gejolak kebutuhan tingkat ekonomi menengah hingga bawah bisa membantu mereka. Dengan wakaf produktif dapat diperoleh akses kepada sumber dana sehingga dihasilkan modal yang memadai. Dana yang diperoleh melalui wakaf produktif dapat digunakan sebagai modal sehingga dapat digunakan untuk pemupukan modal secara berkesinambungan. $^{45}$

Adapun upaya pemberdayaan penyaluran wakaf secara produktif dilakukan dengan melakukan pembangunan beberapa proyek percontohan yang beberapa diantaranya akan diuraikan sebagai berikut:

1) Bidang Pendidikan dan keagamaan

Upaya ini tentu menjadi perhatian bagi nâzir pesantren, nâzir universitas bahkan nâzir masjid sekalipun. Karena dengan sarana dan gedung yang mereka miliki tentu sarana tersebut tidak berarti membebani nâzir dalam mengurus sarana pendidikan dan keagamaan tersebut. Sesungguhnya bisa dengan mengelola sarana tersebut lebih produktif sehingga dalam aspek perawatan dan pemeliharaan sarana tidak malah membebani nâziri.

2) Bidang sosial

Pemerintah Indonesia sudah mulai menggalakkan pemberdayaan wakaf, tidak hanya terbatas pada urusan peribatan juga dilaksanakan pemberdayaan secara sosial. Ada tiga sudut pandang untuk melihat dan menilai wakaf mengarah pada keadilan sosial. Pertama, sebagai pemenuhan kebutuhan dasar yang meliputi makan, tempat tinggal, pendidikan dan kesehatan. Kedua, sebagai uapaya peningkatan kesempatan yang setara bagi semua orang, terutama bagi mereka yang kurang beruntung. Ketiga, sebagai perubahan struktural yang mencakup

\footnotetext{
45 Ibid.

${ }^{46}$ Miftahul Huda, Mengalirkan Manfaat Wakaf, 242
} 
perubahan sistem dan pranata sosial yang kurang memihak kepada masyarakat kurang mampu. ${ }^{47}$ Sebagai contoh adalah panti asuhan.

3) Bidang ekonomi

Prospek ekonomi harta wakaf dianggap cukup baik dan potensial yang dapat diwujudkan dengan berbagai kebijakan yang sesuai tergantung keadaan masing-masing harta wakaf tersebut. Pihak manajemen harta wakaf perlu lebih dinamis dan lebih berani melakukan perubahanperubahan yang sesuai dengan syariat sehingga harta wakaf tersebut lebih peroduktif dan memberi maslahat yang lebih besar. Perubahanperubahan ini antara lain mengubah atau mengganti harta wakaf, mengalihkan harta wakaf, menggabungkan harta wakaf, mengubah persyaratan wakaf dan lain-lain secara baik. ${ }^{48}$

Menurut Muhammad Abdul Mannan pemberdayaan ekonomi masyarakat salah satu indikator efektifitas wakaf uang adalah income redistribution (redistribusi pendapatan). Pengeluaran dana-dana yang diperoleh dari hasil pengelolaan wakaf berperan penting pada setiap redistribusi pendapatan secara vertical. ${ }^{49}$

Berdasarkan uraian di atas dapat disimpulkan bahwa pemanfaatan wakaf produktif mempunyai tujuan untuk kemaslahatan masyarakat dengan memanfaatkan benda yang diwakafkan secara berkesinambungan untuk kesejahteraan umat, pengembangan rumah sakit Islam, bantuan pemberdayaan ekonomi umat dan bantuan atau pengembangan sarana prasarana ibadah.

\section{Kesimpulan}

Pengelolaan wakaf harus diperluas pemanfaatannya. Pemanfaatan wakaf yang lebih dominan untuk pembangunan sekolah dan tempat ibadah, harus didorong juga agar menyentuh pada pembangunan sektor usaha yang produktif agar benefit yang dihasilkan menjadi lebih besar. Hasil dari pemberdayaan umat secara produktif dapat dikembangkan untuk pengembangan pendidikan, sarana kesehatan, dakwah, kegiatan sosial, serta untuk memperkuat perekonomian dan kesejahteraan umat.

Pengelolaan wakaf yang ditujukan untuk memperkuat perekonomian umat dapat dilakukan dengan memanfaatkan berbagai alternatif program yang pendanaannya bersumber dari wakaf. Pencapaian tujuan penggunaan wakaf memerlukan manajemen pengelolaan yang

\footnotetext{
47 Abdul Wadud Nafis, Manajemen Pengelolaan Wakaf Tunai, 51

48 Suhrawardi K. Lubis, Wakaf dan Pemberdayaan Umat, (Jakarta: Sinar Grafika, 2010), 97

${ }^{49}$ Rozalinda, ManajemenWakaf Produktif, (Jakarta: Raja Grafindo Persada, 2015), 289
} 
profesional sehingga perlu ditangani oleh SDM yang kompeten. Posisi nadhir sangat signifikan dalam menentukan tercapainya tujuan pemberdayaan wakaf, karena terkait langsung dengan keberhasilan pengelolaan wakaf. Pengelola wakaf (nadhir) harus memiliki manajemen pengelolaan yang baik agar potensinya dapat dikembangkan untuk kesejahteraan umat.

\section{Daftar Pustaka}

Achmad Djunaidi dan Thobib Al-Asyhar. 2007. Menuju Era Wakaf Produktif. Jakarta: Mumtaz Publishing.

Abdurrahman. 1994. Masalah Perwakafan Tanah Milik dan Kedudukan Tanah Wakaf di Negara Kita, cet. 4. Bandung: Citra Aditya Bakti

Al Arif, M. Nur Rianto. 2012. Jurnal Ilmu Syariah dan Hukum, Efek Multiplier Wakaf Uang dan Pengarubnya terbadap Program Pengentasan Kemiskinan

al-Khadami, Nuruddin.2006. Al-Waqf al-'Alami. Tunisia: tp

Bungin, Burhan. 2001. Metodologi Penelitian Sosial. Sidoarjo: Airlangga University Press

Departemen Agama, Undang-Undang Nomor 41 Tahun 2004

Departemen Agama, Undang-Undang Nomor 42 Tahun 2006

Depag RI. 2007. Paradigma Baru Wakaf di Indonesia. Jakarta: Direktorat Pemberdayaan Wakaf \& Direktorat Jendral Bimbingan Masyarakat Islam

Effendi, Satria. 2010. Problematika Hukum Keluarga Islam Kontemporer, Analisis Yurisprudensi dengan Pendekatan Ushuliyah. Jakarta: Kencana Prenada Media Group

Farid Wadjdy \& Mursyid. 2007. Wakaf dan Kesejabteraan Umat. Samarinda: Pustaka Pelajar

Huda, Miftahul. 2015.Mengalirkan Manfaat Wakaf. Bekasi: Gramata Publishing

PW. Lembaga Wakaf dan Pertanaban NU Jawa Timur, Buku Panduan Wakaf Tanah dan Tanah HakMilik Atas Nama Nahdatul Ulama. Jakarta: Pengurus Besar Nahdlatul Ulama, 2006

Wadud Nafis, Abdul. 2011. Manajemen Pengelolaan Wakaf Tunai. Lumajang: LP3DI

Departemen Agama. 2007.Undang-Undang Nomor 41 Tabun 2004 Tentang Wakaf. Surabaya: Kantor Wilayah Provinsi Jawa Timur

Kementrian Agama RI. 2013.Panduan Pengelolaan Wakaf Tunai. Jakarta: Direktorat Jendral Bimbingan Masyarakat Islam Direktorat Pemberdayaan Wakaf 
K. Lubis, Suhrawardi. 2010. Wakaf dan Pemberdayaan Umat. Jakarta: Sinar Grafika

Manan, M. Abd. 1993.Ekonomi Islam Teori dan Praktek, M. Nastangin (terj). Yogyakarta: Dana Bhakti Wakaf.

Muzarie, Mukhlisin. 2010.Fiqh Wakaf. Yogyakarta: Dinamika STAIC Press

Mubarok, Jaih. 2008. Wakaf Produktif. Bandung: Simbiosa Rekatama Media

Qahaf, Mundzir. 2005. Manajemen Wakaf Produktif, terjemah Rida, Mas Mubyiddin. Jakarta: Khalifa

Rozalinda. 2015. Manajemen Wakaf Produktif. Jakarta: Raja Grafindo Persada

Rozalinda. 2015.Manajemen Wakaf Produktif. Jakarta: Raja Grafindo Persada

Syukron, Ahmad. 2011.Rekonstruksi Hukum Islam: Kajian Historis Atas Urgensi Pelembagaan Wakaf Produktif di Indonesia.Jurnal Penelitian

Saroso \& Nicongani. 1984.Tinjauan Yuridis tentang Perwakafan Tanah Milik, Seri Hukum Agraria No.1.Yogyakarta: Liberty

Undang-Undang Perkawinan di Indonesia dilengkapi Kompilasi Hukum Islam. Surabaya: Arkola, t:th.

Zuhayli, Wahbah. 1985. Al-Fiqhu al-Islami wa 'Adillatuhu Juz 8. Damaskus:

Dar al-Fikr 